\title{
Nutrient distribution pattern and uptake by different sugarcane genotypes at different growth stages
}

S. Rama Lakshmi, T. Sreelatha and A. Sireesha

Received : 26.10.2019; Revised : 14.11.2019; Accepted : 25.11.2019

MEMBERS OF RESEARCH FORUM:

Corresponding author : S. Rama Lakshmi, Regional Agricultural Research Station, Anakapalle, Visakhapatnam (A.P.) India

Email: sitaramalakshmi20@yahoo. com

Co-authors :

T. Sreelatha and A. Sireesha, Regional Agricultural Research Station, Anakapalle,

Visakhapatnam (A.P.) India

\section{Summary}

Experiment was conducted at Regional Agricultural Research Station, Anakapalle during 201314 to study the distribution of macro and micronutrients in sugarcane leaf, sheath and whole plant at different growth stages and their uptake by whole plant in different sugarcane genotypes/varieties. Six genotypes were selected i.e. 96A3, 98A163, 2000A225 (mid late) and 97A85, 2001 A63 and 2000A56 (early). Results revealed that contents of all the macro and micro nutrients in all the genotypes were decreased from formative to grand growth phase in all the parts of sugarcane i.e. leaf, sheath and whole plant. At formative and grand growth phase more amount of $\mathrm{N}$ and $\mathrm{K}$ was accumulated in leaf followed by sheath and whole plant, where as phosphorus content was highest in leaf followed by whole plant and sheath. Among mid late genotypes highest nitrogen content was observed in 2000A225, phosphorus and potassium content was more in 96A3. In both formative and grand growth phase more zinc, iron and manganese content was recorded in 2000A225, whereas more copper content was recorded in 98A163. Whereas in early genotypes, more nitrogen content was observed in $2001 \mathrm{~A} 63$, phosphorus and potassium content was more in 2000A56 except leaf potassium at formative phase as it was more in 97A85. In both formative and grand growth phase more zinc and iron content was recorded in 2001 A63. Manganese content was more in 97A85, whereas more copper content was recorded in 2000A56. Among different prerelease genotypes 2001 A 63 exhibited highest nitrogen uptake of $219.90 \mathrm{~kg} \mathrm{ha}^{-1}$ followed by $2000 \mathrm{~A} 225(209.78 \mathrm{~kg}$ $\left.\mathrm{ha}^{-1}\right)$ and 97A85 (209.66 kg ha-1), whereas highest P uptake of $62.70 \mathrm{~kg} \mathrm{ha}^{-1}$ was recorded by $2000 \mathrm{~A} 225$ and highest potassium uptake of $264.99 \mathrm{~kg} \mathrm{ha}^{-1}$ and it was closely followed the 2001 A 63 genotype (263.96 $\left.\mathrm{kg} \mathrm{ha}^{-1}\right)$.

Key words : Sugarcane, Nutrient content, Uptake

How to cite this article : Rama Lakshmi, S., Sreelatha, T. and Sireesha, A. (2019). Nutrient distribution pattern and uptake by different sugarcane genotypes at different growth stages. Asian J. Soil Sci., 14 (1\&2) : 67-72 : DOI : 10.15740/HAS/AJSS/14.1and2/67-72. 